\title{
Characteristics and source apportionment of fine haze aerosol in Beijing during the winter of 2013
}

\author{
Xiaona Shang ${ }^{1}$, Kai Zhang ${ }^{2}$, Fan Meng ${ }^{2}$, Shihao Wang ${ }^{2}$, Meehye Lee ${ }^{1}$, Inseon Suh ${ }^{1}$, Daigon Kim ${ }^{3}$, Kwonho Jeon ${ }^{3}$, \\ Hyunju Park ${ }^{3}$, Xuezhong Wang ${ }^{2}$, and Yuxi Zhao ${ }^{2}$ \\ ${ }^{1}$ Department of Earth \& Environmental Sciences, Korea University, Seoul, South Korea \\ ${ }^{2}$ State Key Laboratory of Environmental Criteria and Risk Assessment, Chinese Research Academy of Environmental \\ Sciences, Beijing 100012, China \\ ${ }^{3}$ Department of Climate \& Air Quality Research, National Institution of Environmental Research, Incheon, South Korea
}

Correspondence: Kai Zhang (zhangkai@craes.org.cn) and Meehye Lee (meehye@korea.ac.kr)

Received: 1 June 2017 - Discussion started: 12 June 2017

Revised: 15 November 2017 - Accepted: 27 November 2017 - Published: 21 February 2018

\begin{abstract}
For $\mathrm{PM}_{2.5}$ filter samples collected daily at the Chinese Research Academy of Environmental Sciences (Beijing, China) from December of 2013 to February of 2014 (the winter period), chemical characteristics and sources were investigated with an emphasis on haze events in different alert levels. During the 3 months, the average $\mathrm{PM}_{2.5}$ concentration was $89 \mu \mathrm{g} \mathrm{m}^{-3}$, exceeding the Chinese national standard of $75 \mu \mathrm{g} \mathrm{m}^{-3}$ in $24 \mathrm{~h}$. The maximum $\mathrm{PM}_{2.5}$ concentration was $307 \mathrm{~g} \mathrm{~m} \mathrm{~m}^{-3}$, which characterizes developedtype pollution $\left(\mathrm{PM}_{2.5} / \mathrm{PM}_{10}>0.5\right)$ in the World Health Organization criteria. $\mathrm{PM}_{2.5}$ was dominated by $\mathrm{SO}_{4}^{2-}, \mathrm{NO}_{3}^{-}$, and pseudo-carbonaceous compounds with obvious differences in concentrations and proportions between non-haze and haze episodes. The non-negative matrix factorization (NMF) analysis provided reasonable $\mathrm{PM}_{2.5}$ source profiles, by which five sources were identified: soil dust, traffic emission, biomass combustion, industrial emission, and coal combustion accounting for $13,22,12,28$, and $25 \%$ of the total, respectively. The dust impact increased with northwesterlies during non-haze periods and decreased under stagnant conditions during haze periods. A blue alert of heavy air pollution was characterized by the greatest contribution from industrial emissions $(61 \%)$. During the Chinese Lantern Festival, an orange alert was issued and biomass combustion was found to be the major source owing to firework explosions. Redalert haze was almost equally contributed by local traffic and transported coal combustion emissions from the vicinity of Beijing (approximately $40 \%$ each) that was distinguished by the highest levels of $\mathrm{NO}_{3}^{-}$and $\mathrm{SO}_{4}^{2-}$, respectively. This study
\end{abstract}

also reveals that the severity and source of haze are largely dependent on meteorological conditions.

\section{Introduction}

With the increasing $\mathrm{PM}_{2.5}$ concentration in northern China, winter haze occurrences increased from 3 to 16 days per year during 2000-2012 (Wang and Chen, 2016). The frequency of haze events during winter is enhanced by meteorological conditions; the minimum daily temperatures typically reach -15 to $-20^{\circ} \mathrm{C}$ (Wu et al., 2012) and the boundary layer height becomes shallow, to less than $100 \mathrm{~m}$ (Zheng et al., 2015). Moreover, the combustion of fossil fuel increases at low temperatures (Zhang and Samet, 2015). As the air quality deteriorated, China released its third revision of the "The National Ambient Air Quality Standards" (NAAQS) in 2012 (GB3095-2012), which stipulated safe $\mathrm{PM}_{2.5}$ levels for the first time (Zhang and Cao, 2015). However, the worst haze events in the major cities of China were recorded during the winter of 2012-2013. During January of this period, Beijing experienced almost daily haze and the hourly $\mathrm{PM}_{2.5}$ concentration reached $855 \mathrm{\mu g} \mathrm{m}^{-3}$ (Zheng et al., 2015). In Beijing, winter haze episodes lasted 5 days (Zheng et al., 2015, 2016). The long duration of haze with high $\mathrm{PM}_{2.5}$ concentration triggers a red alert for air pollution (Liu et al., 2017), which is the highest level of the heavy air pollution warning system issued in the "Emergency plan for heavy air pollution in Beijing" (revised in 2016; in Chi- 
nese: http://zhengce.beijing.gov.cn/zhengce/197/1861/1921/ 1005141/1283071/index.html).

The concentrations of $\mathrm{SO}_{2}, \mathrm{NO}_{x}$, and volatile organic compounds (VOCs), which are important precursors of $\mathrm{PM}_{2.5}$, vary by emission and policy implementations. Related particulate compositions (sulfate, nitrate, and organic matter) comprise two-thirds of $\mathrm{PM}_{2.5}$ (Huang et al., 2014; $\mathrm{Hu}$ et al., 2015). Over a 7-year period (2000-2006), $\mathrm{SO}_{2}$ emission increased by $53 \%$, consistent with the increases in power plant emissions from 10.6 to 18.6 Tg (Lu et al., 2010). Particularly in northern China, the emissions from power plants have increased by $85 \%$ over this period. In contrast, $\mathrm{SO}_{2}$ levels have significantly decreased since 2006, when stricter $\mathrm{SO}_{2}$ regulations, such as the use of flue-gas desulfurization systems or scrubbers, were imposed (Van der A et al., 2016). The reduction was particularly rapid during 2008 2009. On the other hand, the $\mathrm{NO}_{x}$ concentration increased from 2000 to 2012 (Hong et al., 2016; Cao et al., 2011). This increase is in agreement with the increased number of vehicles, which contribute $90 \%$ of the total $\mathrm{NO}_{x}$ emissions in Beijing (Hendrick et al., 2014; Wu et al., 2012). Meanwhile, the continuous increase in VOC emissions (from $13 \mathrm{Tg} \mathrm{yr}^{-1}$ in 2000 to $26 \mathrm{Tg} \mathrm{yr}^{-1}$ in 2012) was mainly driven by industrial processes $(\sim 70 \%$; Hong et al., 2016). Coal combustion (especially that of raw coal) from households is underestimated in the southern and eastern rural areas of Beijing. Rural coal combustion comprises approximately $75 \%$ of Beijing's total coal combustion (Cheng et al., 2017). After the 2008 Olympic Games, residential coal combustion emitted large amounts of $\mathrm{SO}_{2}, \mathrm{NO}_{x}$, and VOCs $(70,17$, and $43 \mathrm{kt}$, respectively). In 2013, these amounts had increased 2-fold to 132, 33, and $81 \mathrm{kt}$, respectively. At the end of 2013, China issued the Air Pollution Prevention and Control Action Plan (CAAC, 2013), which greatly reduced the precursor emissions in 2014 (Wang et al., 2015).

Under the strict regulations on boiler and industrial emissions, $\mathrm{SO}_{2}$ concentrations in Beijing significantly decreased during the winter of 2013 and the fuel sulfur was reduced by more than $80 \%$ in 2014 (relative to its 2013 levels; CAAC, $2013,2015)$. Over the same period, the $\mathrm{NO}_{x}$ levels were reduced by $6.7 \%$ over the nation, but exceeded the standard by $42 \%$ in Beijing, where local traffic emissions remained high. Meanwhile, the $\mathrm{PM}_{2.5}$ pollution is the most severe in the region of southern Beijing, where the annual average concentration reached $150 \mathrm{\mu g} \mathrm{m}^{-3}$ during 2014-2015. The level is comparable to the national standard of $\mathrm{PM}_{10}$ (CAAC, 2015; Zhang and Cao, 2015).

Since the 2008 Olympics and 2013 CAAC, heavy industries have been relocated and high-quality fuel has been introduced. Both actions have reduced the concentrations of gaseous precursors (Wang et al., 2009; Van der A et al., 2016), although these reductions are in contrast to the frequent hazes currently observed in Beijing. In recent studies, the $\mathrm{PM}_{2.5}$, dust, and $\mathrm{SO}_{2}$ concentrations in Beijing have been mainly attributed to regional transport (Wang et al., 2014,
2011; Yang et al., 2013). Considering the extreme haze situation in Beijing, researchers have sought the crucial factors of haze formation, usually by identifying the emission sources of $\mathrm{PM}_{2.5}$. The source apportionment of $\mathrm{PM}_{2.5}$ is commonly analyzed by source receptor models such as positive matrix factorization (PMF) and non-negative matrix factorization (NMF; Reff et al., 2007; Kfoury et al., 2016). These models have implicated coal and industries as major sources of $\mathrm{PM}_{2.5}$ in Beijing (Huang et al., 2014; Zhang and Cao, 2015; Zhang et al., 2013).

Following the severe and frequent haze occurrences in January of 2013, the chemical characteristics and sources of $\mathrm{PM}_{2.5}$ in Beijing were extensively investigated (Jiang et al., 2015; Zheng et al., 2015; Zhang et al., 2015; Chen et al., 2017). However, few studies have investigated the winter season of 2013-2014, which immediately followed the enactment of the 2013 CAAC in China. In particular, the source apportionment of Beijing's haze remains unknown (Wu et al., 2016). In the present study, we thoroughly examine the chemical compositions of $\mathrm{PM}_{2.5}$ in Beijing during the winter of 2013-2014, and accordingly, diagnose the haze occurrence, probe the local and transported influence on haze, and quantify the critical source contributions.

\section{Experiments}

Filtered samples of $\mathrm{PM}_{10}$ and $\mathrm{PM}_{2.5}$ were collected on the roof of a three-story container ( $\sim 15 \mathrm{~m}$ above ground level) at the Chinese Research Academy of Environmental Sciences (CRAES) in Beijing, China $\left(40.04^{\circ} \mathrm{N}, 116.42^{\circ} \mathrm{E}\right)$, from December of 2013 to February of 2014. The site is located near a four-way intersection of a residential area located between the 5th and 6th ring roads of Beijing.

Aerosols were collected for $24 \mathrm{~h}$ (from 19:00 to 19:00 the following day) on a $90 \mathrm{~mm}$ polypropylene filter using a medium volume sampler at a flow rate of $\sim 100 \mathrm{~L} \mathrm{~min}^{-1}$ (2030, Laoying, China). Seventy $\mathrm{PM}_{2.5}$ samples were collected and analyzed. The water-soluble ions $\left(\mathrm{Cl}^{-}, \mathrm{NO}_{2}^{-}\right.$, $\mathrm{CO}_{3}^{2-}, \mathrm{SO}_{4}^{2-}, \mathrm{NO}_{3}^{-}, \mathrm{Na}^{+}, \mathrm{NH}_{4}^{+}, \mathrm{K}^{+}, \mathrm{Mg}^{2+}$, and $\mathrm{Ca}^{2+}$ ) were measured by ion chromatography (IC25, Dionex, USA) with a detection limit between 0.01 and $0.06 \mu \mathrm{g} \mathrm{m}^{-3}$. The ionic measurement method is detailed in Lim (2009). For trace elemental analysis, the samples were digested by a mixture of acids as described in Zhang et al. (2014). A quarter of each filter was placed into a polytetrafluoroethylene flask and digested with $8 \mathrm{~mL}$ of $\mathrm{HNO}_{3} / \mathrm{H}_{2} \mathrm{O}_{2}(6 / 2 v / v$, superpure grade, Merck, Darmstadt, Germany) at $180^{\circ} \mathrm{C}$ for $8 \mathrm{~h}$. The solution was separated by centrifugation and diluted to $25 \mathrm{~mL}$ with ultrapure water. The concentrations of trace metals ( 21 species, including $\mathrm{Si}$ ) were determined by inductively coupled plasma optical emission spectrometry (Prodigy 7, Teledyne Leeman, USA). The mass concentration of $\mathrm{PM}_{10}$ was also determined for comparison with that of $\mathrm{PM}_{2,5}$. 
The total concentrations of the water-soluble ions and trace elements were subtracted from the $\mathrm{PM}_{2.5}$ mass, to provide a measure that likely represents the carbonaceous components that were not directly measured. In this study, therefore, it was referred as the pseudo-carbonaceous components and used for the following discussion. The concentrations of these pseudo-carbonaceous components were comparable to those of $\mathrm{PM}_{2.5}$ concentrations observed in Beijing (Ji et al., 2016). A meteorological suite of relative humidity, temperature, and visibility was collected by CRAES from a sharing network of the China Meteorological Data Service Center (CMDC; http://data.cma.cn/en/?r=data/detail\&dataCode=A. 0012.0001). The gaseous species $\mathrm{NO}_{x}, \mathrm{SO}_{2}, \mathrm{CO}$, and $\mathrm{O}_{3}$ were measured using commercial analyzers (42i, 43i, 48i, 49i, Thermo Fisher, USA) in CRAES.

The $\mathrm{PM}_{2.5}$ source was identified by non-negative matrix factorization (NMF) analysis. Introduced by Lee and Seung (1999, 2001), NMF operates similarly to positive matrix factorization (PMF). Both analysis methods find two matrices ( $\mathbf{W}$ and $\mathbf{H}$, termed the contribution matrix and the source profile matrix, respectively) that best reproduce the input data matrix $(\mathbf{V})$ using the same factorization approach $(\mathbf{V}=\mathbf{W H})$ as a positive constraint. However, while PMF is a generalized, alternative least-squares method, NMF minimizes the conventional least-squares error and the generalized Kullback-Leibler divergence. The uncertainties in NMF analysis were estimated as 0.3 plus the analytical detection limit (Xie et al., 1999a, b).

In addition to NMF analysis, the origin of air masses was traced by trajectory analysis. For air masses arriving at $500 \mathrm{~m}$ altitude, backward trajectories were computed for $72 \mathrm{~h}$ using HYSPLIT model with GDAS data in SplitR (Stein et al., 2015, https://github.com/rich-iannone/ SplitR).

\section{Characteristics of winter $\mathbf{P M}_{2.5}$}

\section{1 $\mathrm{PM}_{2.5}$ and $\mathrm{PM}_{10}$ mass variations}

During the 2013-2014 winter period in Beijing, the mass concentrations of $\mathrm{PM}_{2.5}$ and $\mathrm{PM}_{10}$ varied in a similar pattern (Fig. 1). Zheng et al. (2015) reported a similar trend between the $\mathrm{PM}_{2.5}$ and $\mathrm{PM}_{10}$ concentrations. In this study, the average $\mathrm{PM}_{10}$ concentration was $142 \mu \mathrm{g} \mathrm{m}^{-3}$, comparable to the Chinese national standard of $150 \mu^{-3} \mathrm{~m}^{-3}$ in $24 \mathrm{~h}$ (GB3095-2012). However, the mean $\mathrm{PM}_{2.5}$ concentration was $89 \mu \mathrm{g} \mathrm{m}^{-3}$, exceeding the standard of $75 \mu \mathrm{g} \mathrm{m}^{-3}$ in $24 \mathrm{~h}$. The $\mathrm{PM}_{2.5}$ standard was most severely exceeded in February 2014 , when the average concentration $\left(133.5 \mu \mathrm{g} \mathrm{m}^{-3}\right)$ reached the highest winter concentration in Beijing during 2005-2015 (Lang et al., 2017).

Based on the criteria of the World Health Organization (WHO; 2006), the wintertime air pollution of Beijing was classified as developed type, meaning that the $\mathrm{PM}_{2.5} / \mathrm{PM}_{10}$ ratio exceeded 0.5 in $70 \%$ of the samples (Table 1). The
Table 1. Statistics of $\mathrm{PM}_{2.5}$ mass concentrations.

\begin{tabular}{l|r|r}
\hline $\mathrm{PM}_{2.5}$ mass classification & Number & $\begin{array}{r}\mathrm{PM}_{2.5}^{\mathrm{a}} \\
{\left[\mu \mathrm{g} \mathrm{m}^{-3}\right]}\end{array}$ \\
\hline Chemical and NMF analysis & 70 & \\
\hline Comparison with $\mathrm{PM}_{10}$ mass & 67 & 89 \\
$\mathrm{PM}_{2.5} / \mathrm{PM}_{10}>0.5$ & 47 & 113 \\
$\mathrm{PM}_{2.5}>75 \mu \mathrm{g} \mathrm{m}^{-3}$ and $\mathrm{PM}_{10}>150 \mu \mathrm{g} \mathrm{m}^{-3}$ & 23 & 168 \\
$\mathrm{PM}_{2.5}>75 \mu \mathrm{g} \mathrm{m}^{-3}$ and $\mathrm{PM}_{10}<150 \mu \mathrm{g} \mathrm{m}^{-3}$ & 5 & 113 \\
$\mathrm{PM}_{2.5}<75 \mu \mathrm{g} \mathrm{m}^{-3}$ and $\mathrm{PM}_{10}<150 \mu \mathrm{g} \mathrm{m}^{-3}$ & 19 & 39 \\
$\mathrm{PM}_{2.5} / \mathrm{PM}_{10} \leq 0.5$ & 20 & 31 \\
\hline Haze days $^{\mathrm{a}}$ & 13 & 198 \\
Red alert & 6 & 218 \\
Orange alert & 3 & 216 \\
No/blue alert & 4 & 168 \\
\hline
\end{tabular}

${ }^{\mathrm{a}}$ Average concentration. ${ }^{\mathrm{b}}$ Heavy air pollution alert.

mean $\mathrm{PM}_{2.5}$ concentration of these samples $\left(113 \mu \mathrm{g} \mathrm{m}^{-3}\right)$ was 4 times higher than that in developing-type pollution $\left(31 \mu \mathrm{g} \mathrm{m}^{-3}\right)$. In approximately half of the developed-type samples, the $\mathrm{PM}_{2.5}$ and $\mathrm{PM}_{10}$ mass concentrations exceeded the national standards, all of which were collected during haze events. The average $\mathrm{PM}_{2.5}$ concentration over 13 haze days reached $198 \mu \mathrm{g} \mathrm{m}^{-3}$ and the visibility was significantly reduced to $\sim 1 \mathrm{~km}$ (Fig. 1 ). In contrast, the $\mathrm{PM}_{2.5}$ concentration exceeded the standard without violating the $\mathrm{PM}_{10}$ concentration on only a few days. These results well reflect the wintertime characteristics of $\mathrm{PM}_{2.5}$ levels in Beijing, which are largely related to haze episodes. The average $\mathrm{PM}_{2.5}$ concentration of the developed type was comparable to that of the developing-type unless the $\mathrm{PM}_{2.5}$ concentration exceeded the standard.

On 12 out of 13 haze days, the pollutant levels met the criteria of heavy air pollution alerts stipulated in the "Emergency plan for heavy air pollution in Beijing" (revised in 2016). In the lowest level of the four-tier warning system, blue alert, the daily average air quality index (AQI) exceeded 200 on only 1 day. In Table 1 , the one no alert and three bluealert haze days are defined as no/blue-alert haze events. The average $\mathrm{PM}_{2.5}$ concentration on these days was $168 \mu \mathrm{g} \mathrm{m}^{-3}$ (Table 1). During the red-alert period (February 20-25), the daily $\mathrm{PM}_{2.5}$ concentration peaked at $306 \mu \mathrm{g} \mathrm{m}^{-3}$. A red alert is declared when the air pollution is heavy and severe. During a red alert, AQI exceeds 200 on 4 consecutive days, 2 consecutive days of which with AQI exceeding 300. Although the daily average AQI remained higher than 300 during the February 14-16 period, this event prompted an orange alert because it continued for only 3 days. The AQI data can be found at http://www.tianqihoubao.com/aqi/beijing-201402. html (in Chinese). Here, we describe episodes in terms of alerts defined in the heavy air pollution system rather than in the haze alert system, because the former definition is based on the daily averaged AQI, whereas the three-tier haze warnings depend on the hourly meteorological parameters (rel- 

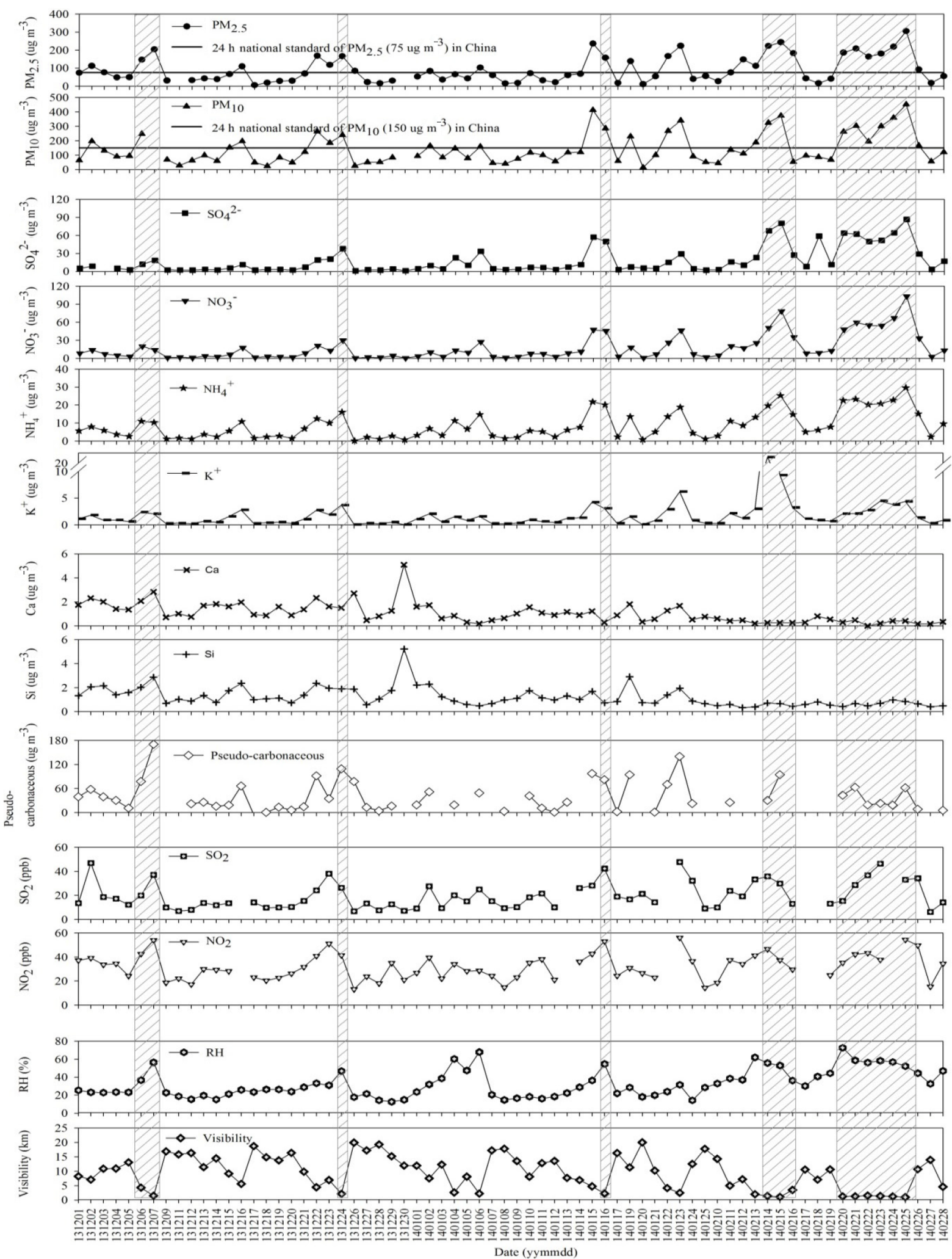

Figure 1. Variations in mass and chemical composition of $\mathrm{PM}_{2.5}, \mathrm{PM}_{10}$ mass, gaseous precursors, and meteorological parameters measured from 1 December 2013 to 28 February 2014. Horizontal lines indicate the Chinese national standards of PM concentrations in $24 \mathrm{~h}$ and the vertically shaded regions denote the 13 haze days. 
Table 2. Sources identified by NMF analysis.

\begin{tabular}{lcl}
\hline Factor & Contribution & Sources \\
\hline Factor 1 & $13 \%$ & soil dust \\
Factor 2 & $22 \%$ & traffic emission \\
Factor 3 & $12 \%$ & biomass combustion \\
Factor 4 & $28 \%$ & industrial emission \\
Factor 5 & $25 \%$ & coal combustion \\
\hline
\end{tabular}

ative humidity and visibility) or $\mathrm{PM}_{2.5}$. Because we measured the daily concentrations, the heavy air pollution alert was suitable for our purpose.

\subsection{Chemical composition}

Throughout the wintertime, the average $\mathrm{PM}_{2.5}$ concentration remained close to $90 \mu \mathrm{g} \mathrm{m}^{-3}, 20 \%$ above the national standard. The major $\mathrm{PM}_{2.5}$ components were $\mathrm{SO}_{4}^{2-}, \mathrm{NO}_{3}^{-}$, $\mathrm{NH}_{4}^{+}$, and pseudo-carbonaceous compounds, with average concentrations of $18.8,16.9,8.5$, and $38.6 \mu \mathrm{g} \mathrm{m}^{-3}$, respectively. Collectively, these four compositions comprised $83 \%$ of the $\mathrm{PM}_{2.5}$ mass (Fig. 2). On the 57 non-haze days, the fractional chemical compositions and concentrations of $\mathrm{SO}_{2}$ and $\mathrm{NO}_{2}$ were comparable to those of the entire period (70 days). In contrast, the portions of soil minerals such as $\mathrm{Ca}^{2+}$ and trace elements (including $\mathrm{Si}$ ) were 3-4 times higher on non-haze days than on haze days. The $\mathrm{Ca}^{2+}$ and Si concentrations were highly correlated $\left(r^{2}=0.8\right)$ and were more related to the $\mathrm{PM}_{10}\left(r^{2}=0.6\right)$ levels than to $\mathrm{PM}_{2.5}$ levels. This reflects the significant impact of soil dust on non-haze days (Fu et al., 2012). On haze days, the particle masses, compositions, $\mathrm{SO}_{2}$, and $\mathrm{NO}_{2}$ varied widely among the different alert levels.

\subsection{Source profiles}

The $\mathrm{PM}_{2.5}$ sources were identified in an NMF analysis of the measurement data. The data included 8 water-soluble ions, 13 trace elements, and pseudo-carbonaceous compounds. After comparison through principal component analysis, the principal factors were determined. Finally, five critical factors were distinguished: soil dust, traffic emission, biomass combustion, industrial emission, and coal combustion (Table 2). The five source profiles are presented in Fig. 3. Despite their clear signatures, the contributions of dust and traffic emissions were approximately half of those of biomass combustion, industrial emission, and coal combustion (Table 2).

Factor 1 (soil dust) is confirmed by high $\mathrm{Ca}^{2+}, \mathrm{Si}, \mathrm{Fe}$, $\mathrm{Cl}^{-}$, and $\mathrm{Na}^{+}$contents (Fu et al., 2012). The high concentrations of $\mathrm{Cl}^{-}$and $\mathrm{Na}^{+}$likely originate from dry lake deposits (Abuduwaili et al., 2015), which are spread over the northern area of Beijing. Elevated heavy metals suggest the presence of fugitive dust mixed with industry or traffic emissions (Wan et al., 2016). The high loadings of $\mathrm{NO}_{3}^{-}$ and $\mathrm{NH}_{4}^{+}$in Factor 2 indicate traffic emissions (He et al., 2016). As is well known, $\mathrm{NH}_{3}$ is emitted from three-way catalytic converters in vehicles (Chang et al., 2016). Factor 3 (biomass combustion) emits large amounts of $\mathrm{K}^{+}$and $\mathrm{NH}_{4}^{+}$(Balasubramanian et al., 1999), along with the elements that give exploding fireworks their color (namely $\mathrm{Mg}$, $\mathrm{Fe}, \mathrm{Al}, \mathrm{Ti}, \mathrm{Cu}$, and $\mathrm{Si}$; Baranyai et al., 2015). The concentrations of these firework indicators are most significantly elevated during the Chinese Lantern Festival (14, 15, and 16 February; Fig. 1). Factor 4 (industrial emissions) is distinguished by high pseudo-carbonaceous materials and heavy metals. Factor 5 (coal combustion) is characterized by high $\mathrm{Cl}^{-}, \mathrm{SO}_{4}^{2-}$, and $\mathrm{NO}_{3}^{-}$contributions, which are absent in Factor 4. Although both Factors 4 and 5 represent the influence of industrial emissions near Beijing, Factor 5 is more clearly sourced from industries requiring high energy, such as iron and steel, cement, and power plants (Tan et al., 2016; Zhang et al., 2013). In contrast, Factor 4 indicates emissions from industrial processes using VOCs as raw materials such as furniture manufacturing, petroleum refining, machinery equipment manufacturing, and printing (Wu et al., 2015).

In a previous study, source apportionment by NMF or PMF analysis distinguished 7-8 factors (Zhang et al., 2013), including a secondary formation source. The secondary source was not separated as an individual factor in the present study. As a typical secondary species, $\mathrm{SO}_{4}^{2-}$ dominates in Factor 5. However, a $\mathrm{NO}_{3}^{-}$signature appears in all factors except Factor 4. As a megacity, Beijing is surrounded by large satellite cities with industrial complexes. Thus, Beijing is susceptible to emissions from these areas in addition to its own emissions when certain meteorological conditions occur. This will be discussed in detail in the following section. In fact, the atmospheric conditions facilitated haze occurrence, leading to the major sources and the degree of aging for aerosols being intimately coupled. Therefore, these five factors primarily represent direct emission sources with secondary sources being implicitly included. In addition, $\mathrm{NO}_{2}$ is more likely sourced from local emissions, but $\mathrm{SO}_{2}$ is expected to be transported from nearby regions.

\section{Characteristics of winter haze}

\subsection{Chemical and meteorological characteristics}

The chemical compositions of $\mathrm{PM}_{2.5}$ clearly differed on haze in contrast to non-haze days in terms of secondary ions and pseudo-carbonaceous compounds (Fig. 2). The largest fraction of pseudo-carbonaceous compounds $(61 \%)$ was accompanied by the smallest proportion of $\mathrm{SO}_{4}^{2-}(4 \%)$ on no/bluealert days, suggesting low coal consumption by high-VOCemitting industries. On orange-alert haze events, the $\mathrm{NO}_{3}^{-}$ fraction was twice that on non-haze days, and the $\mathrm{K}^{+}$and $\mathrm{Mg}^{2+}$ proportions were maximized (at 6 and $1 \%$, respec- 

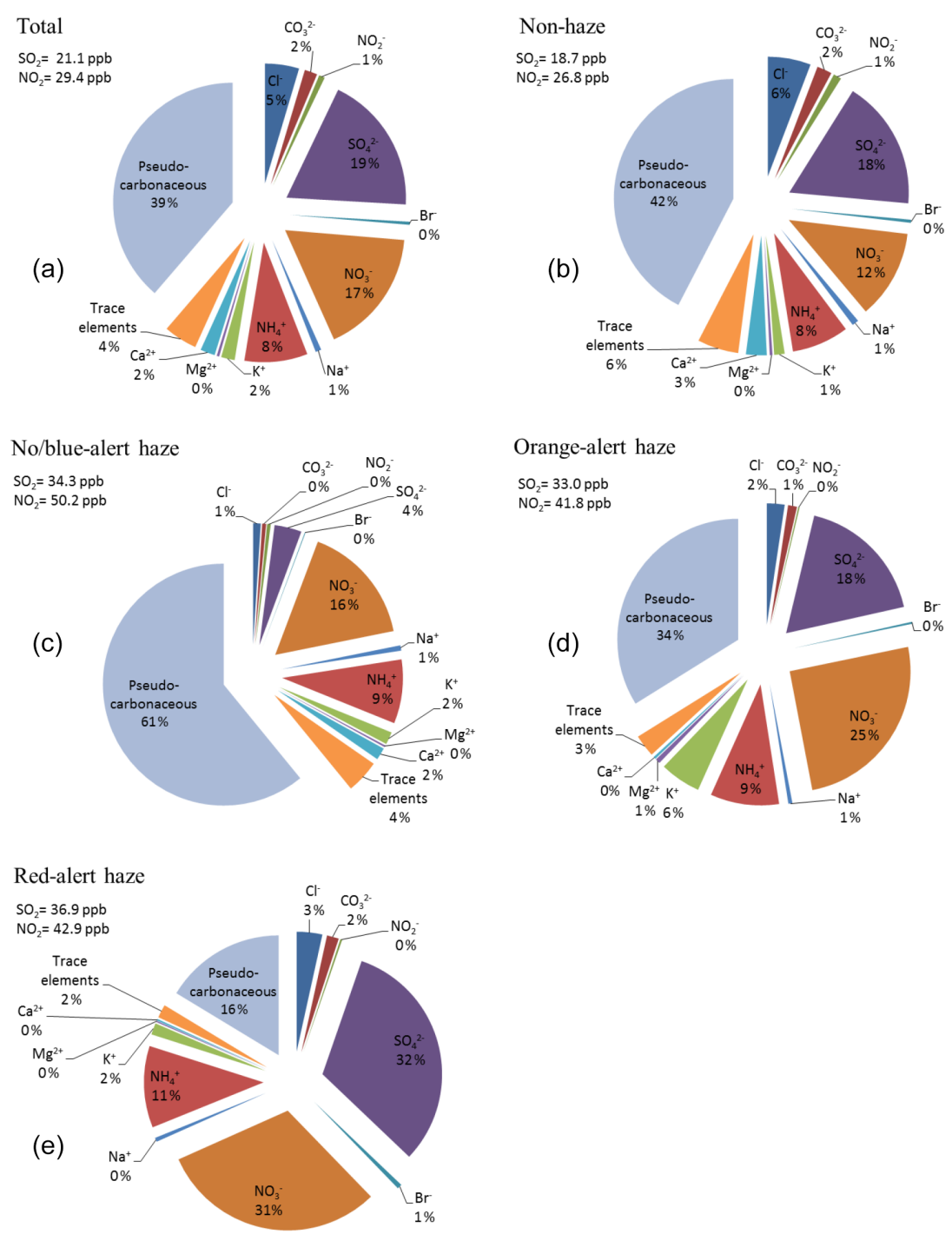

Figure 2. $\mathrm{PM}_{2.5}$ mass contributions of water-soluble ions, trace elements, and pseudo-carbonaceous matter during the entire period (a), nonhaze days (b), and haze days at blue-alert (c), orange-alert (d), and red-alert (e) warning levels. The average $\mathrm{SO}_{2}$ and $\mathrm{NO}_{2}$ concentrations are also given.

tively), implying biomass-combustion emission during the Lantern Festival in China. The concentrations of $\mathrm{SO}_{4}^{2-}$ and $\mathrm{NO}_{3}^{-}$were comparable with the greatest contribution in redalert haze events. In addition, these species were closely related to the $\mathrm{Cl}^{-}\left(r^{2}=0.8\right)$ and $\mathrm{NH}_{4}^{+}\left(r^{2}=0.9\right)$ concentrations, respectively, suggesting large contributions by coal combustion and vehicle emission. It is also noteworthy that the $\mathrm{SO}_{4}^{2-}$ fraction varied more widely than the $\mathrm{NO}_{3}^{-}$fraction (Table $\mathrm{S} 1$ in the Supplement). Among the three levels of haze events, $\mathrm{SO}_{4}^{2-}$ varied from 4 to $32 \%$, whereas $\mathrm{NO}_{3}^{-}$varied from 16 to $31 \%$ and $\mathrm{NH}_{4}^{+}$from 9 to $11 \%$. Similarly, although both $\mathrm{SO}_{2}$ and $\mathrm{NO}_{2}$ concentrations were the highest in red-alert haze, $\mathrm{SO}_{2}$ enhancement (relative to non-haze days) was $20 \%$ larger than $\mathrm{NO}_{2}$ enhancement. Because the sulfur compounds were much more elevated than the nitrogen com- pounds on haze days (particularly in red-alert haze events), it was concluded that coal combustion, which emits sulfur compounds, was the largest contributor to the winter haze in Beijing. Furthermore, coal emissions are mostly transported from near Beijing (Hendrick et al., 2014).

To examine the meteorological conditions favorable for haze occurrence and clarify the emission source regions, surface weather maps combined with daily average backward trajectories at $500 \mathrm{~m}$ were compared during non-haze and haze events. Previous studies also reported that weather conditions were critical for haze formation. In eastern China, migratory anticyclones and weak pressure gradients were the prerequisites of winter haze from 1980 to 2012 (Peng et al., 2016). High $\mathrm{PM}_{2.5}$ episodes in Beijing usually began with weak southerly winds and ended with strong northerly winds 


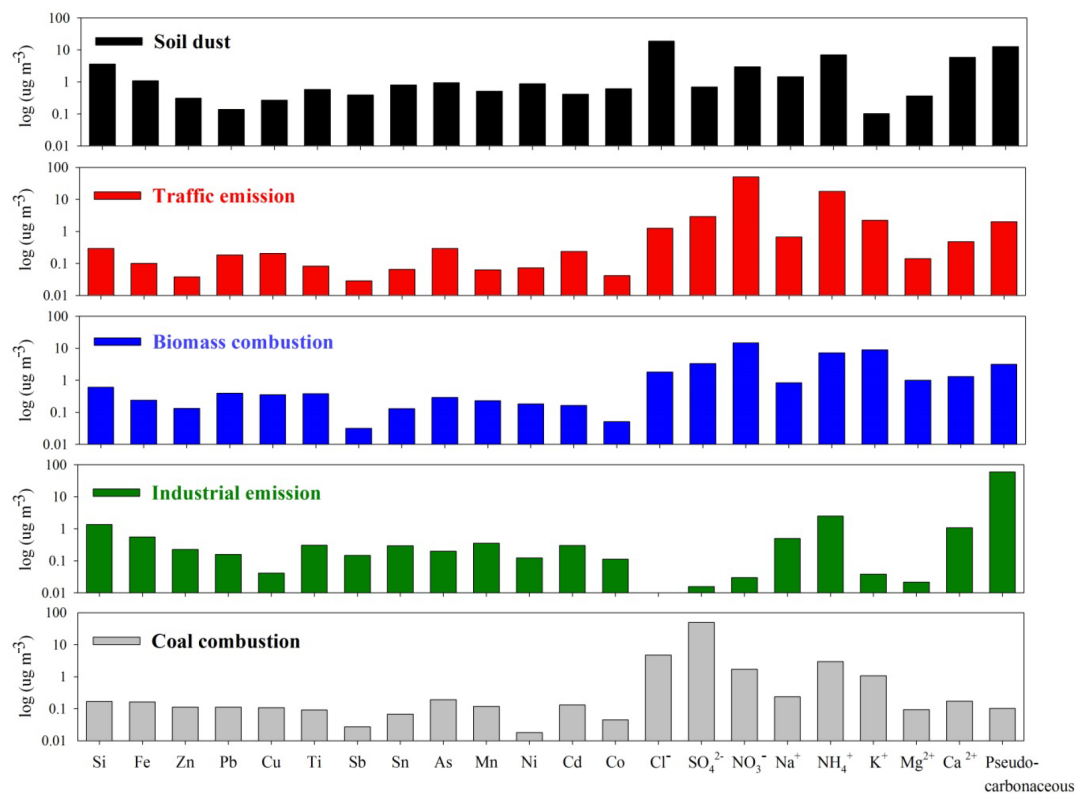

Figure 3. Composition profiles of the five factors identified in NMF analysis.

(Guo et al., 2014). In this study, the air mass was usually transported from the northwest. As the high-pressure system expanded, however, it was transported from the west, southwest, and southeast. Throughout this process, weather conditions became increasingly stagnant (Fig. 4) and the haze alert level increased gradually. The recent study also emphasized the effect of meteorological conditions on the severity of haze in Beijing (Cai et al., 2017). When air masses were rapidly transported from the northern desert area (Fig. 4a), mineral species such as $\mathrm{Ca}^{2+}$ and Si were enriched on non-haze days and the $\mathrm{PM}_{10}$ mass was high. In the western regions of Beijing (Fig. 4b), where various industries manufacture food, drink, furniture, pharmaceuticals, and other products from VOCs (http://www.berkeleysg.com/ 2016/06/china-manufacturing-distribution-map/), the fraction of pseudo-carbonaceous compounds rose to its maximum as the air mass slightly lingered over the region. During 14-16 February, firework explosions caused a spike in $\mathrm{K}^{+}$, $\mathrm{Mg}^{2+}$, and $\mathrm{NH}_{4}^{+}$concentration under the stagnant weather conditions, in which the air mass moved very slowly from the southwestern areas, where population density is the highest (Cheng et al., 2017). As the air mass moved eastward toward the high-energy-requiring regions (http://berc.berkeley. edu/energy-access-developing-parts-china/; Fig. 4d), such as Tianjin and Tangshan, where coal consumption is high for industrial use and residential heating (Cheng et al., 2017), the $\mathrm{PM}_{2.5}$ and $\mathrm{SO}_{4}^{2-}\left(\mathrm{SO}_{2}\right)$ concentrations reached their maxima.

\subsection{Source profiles}

To quantify each source contribution during the winter haze in Beijing, daily samples were analyzed by NMF and the source profiles during haze and non-haze episodes were compared (Fig. 5). In all samples, the main contributions were industrial, traffic, and coal combustion emissions (22-28\%), followed by soil dust and biomass combustion (13 and 12\%, respectively). However, soil dust loading, which is associated with elevated fractions of $\mathrm{Ca}, \mathrm{Si}$, and pseudo-carbonaceous matters (Fig. 2), was enhanced to $20 \%$ during non-haze events. Meanwhile, the local traffic contribution decreased as the air mass was rapidly transported from the northwestern desert areas, as mentioned in Sect. 4.1.

The three types of haze episodes exhibited strong contrasts not only in their chemical species and source regions, as mentioned above, but also in their source profiles (Fig. 5). No/blue-alert haze was dominated by industrial emissions $(61 \%)$ as the airflow passed over the industrial regions manufacturing products from raw VOCs. Consequently, the pseudo-carbonaceous concentration increased. During orange- and red-alert haze events, the dust contribution was negligible and the anthropogenic fraction increased sharply. During the Chinese Lantern Festival (which triggered an orange alert), a biomass signature with the highest $\mathrm{K}^{+}$concentration was observed in the air mass transported from the southwestern populated areas of Beijing. The $\mathrm{K}^{+}$ contribution (35\%) was 3 times higher than that on nonhaze days. During February 20-25, the outflow of the high coal-consuming eastern region enhanced the proportion of coal combustion products to $37 \%$. Simultaneously, the traffic contribution was the highest at $43 \%$. The coal and traffic 
(a)

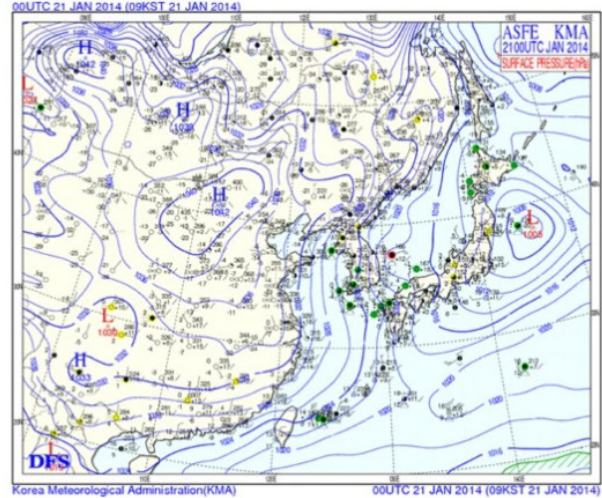

(b)

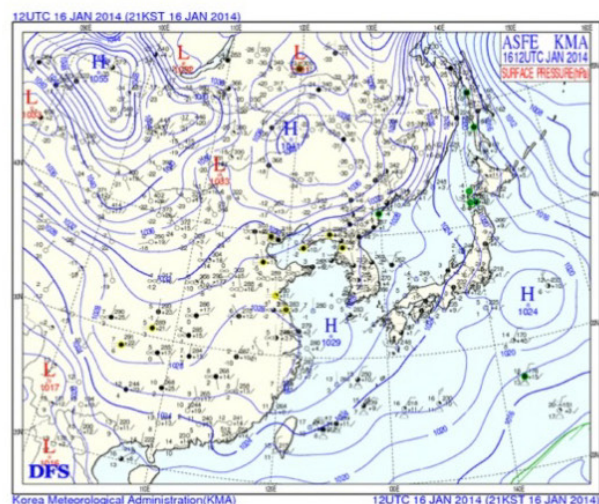

(c)

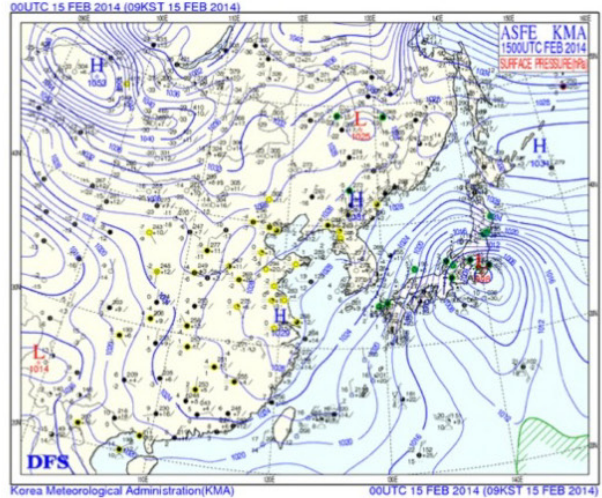

(d)

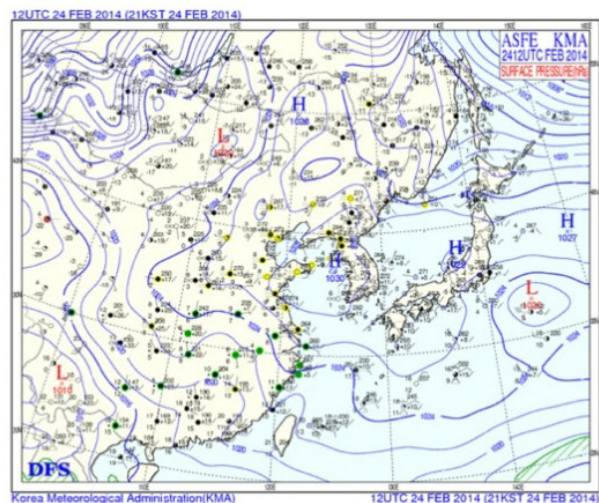

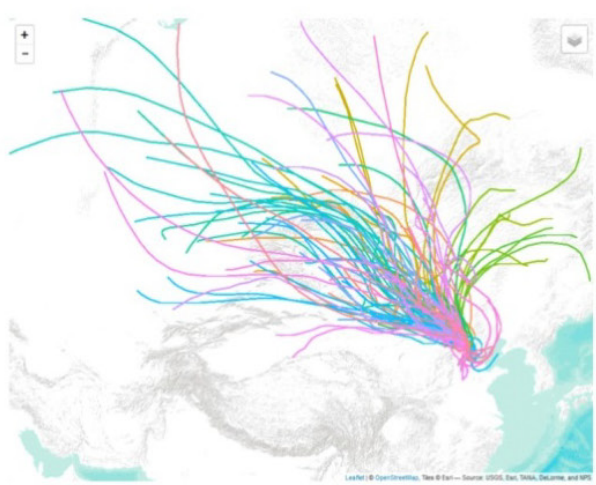
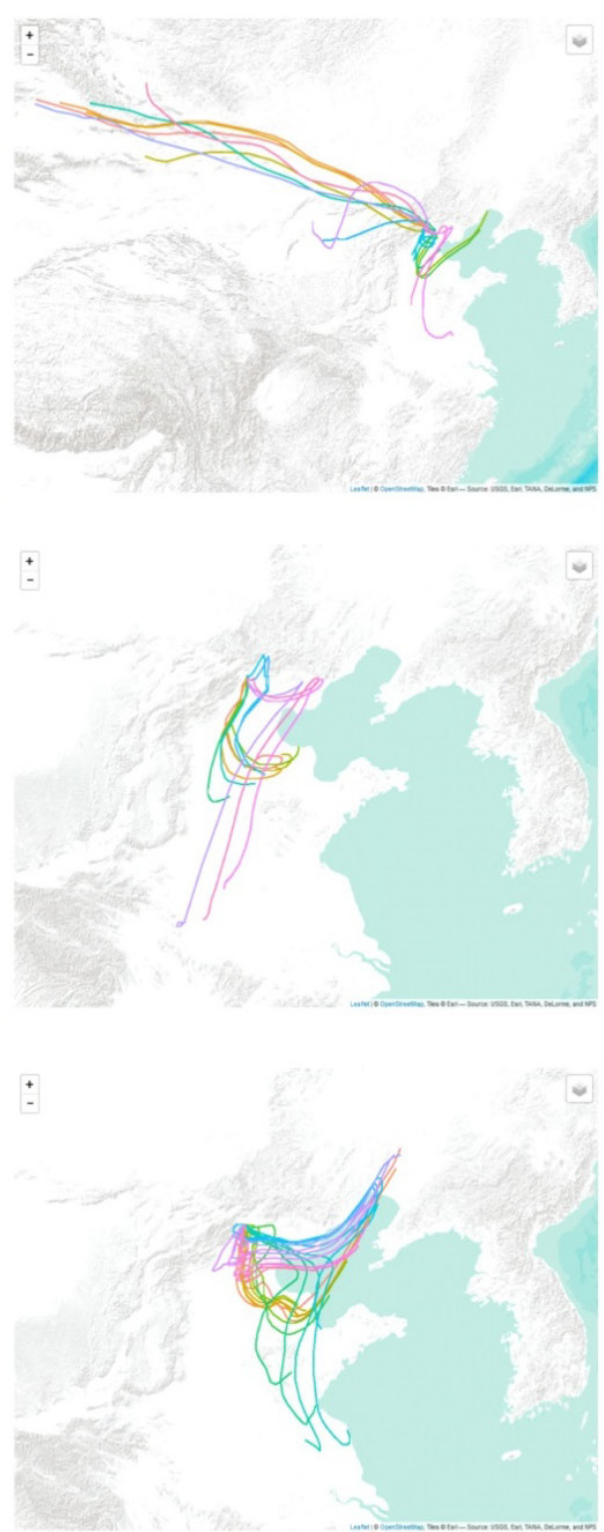

Figure 4. Surface weather maps and $72 \mathrm{~h}$ backward trajectories on days of (a) non-haze (57 days), (b) no/blue-alert haze (4 days), (c) orangealert haze (3 days), and (d) red-alert haze (6 days). Trajectories were calculated twice a day at 18:00 and 06:00 UTC for non-haze days in (a) and every $6 \mathrm{~h}$ at 12:00, 18:00, 24:00, and 06:00 UTC for haze days in (b, c, d). 


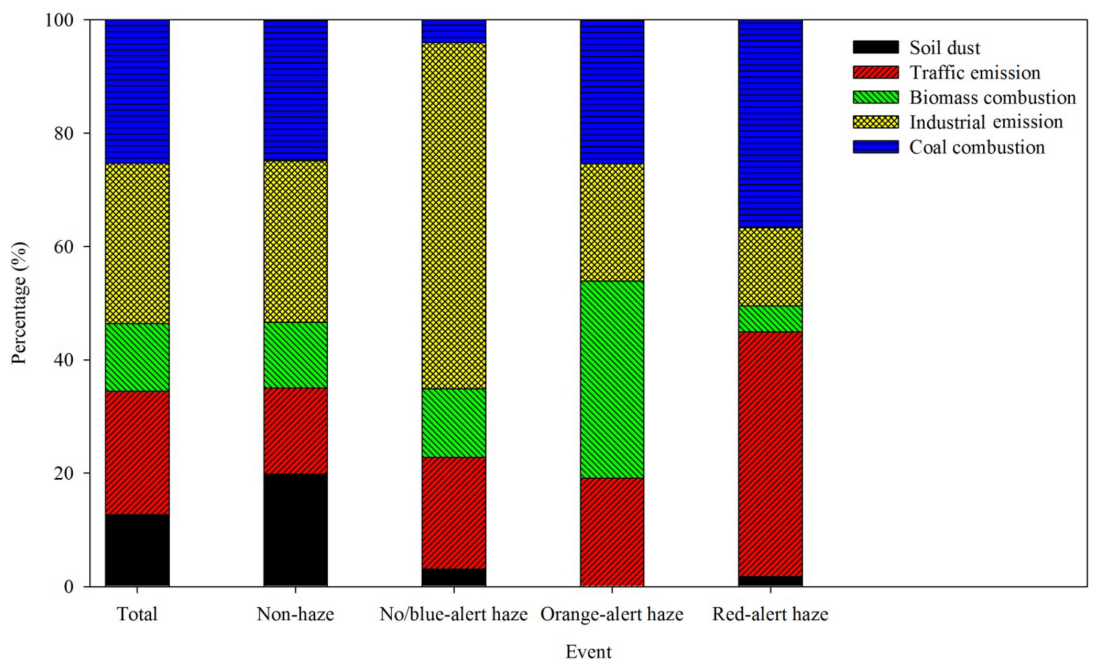

Figure 5. Comparison of source contributions (left to right) over the entire winter, during non-haze events, and during no/blue-alert, orangealert, and red-alert haze events.

effects were accompanied by 2-fold increases in $\mathrm{SO}_{4}^{2-}$ and $\mathrm{NO}_{3}^{-}$in $\mathrm{PM}_{2.5}$.

\section{Policy implications}

During the 2013-2014 winter period in Beijing, the average $\mathrm{PM}_{2.5}$ concentration exceeded the standard by $20 \%$, and in February reached its highest level over 2005-2015 (Lang et al., 2017). The $\mathrm{PM}_{2.5}$ mass closure and concentration of gaseous precursors during the 57 non-haze days were comparable to those of the entire winter period. Mineral dust is an important source of $\mathrm{PM}_{2.5}$ and elevates the $\mathrm{PM}_{10}$ concentration on non-haze days. The average $\mathrm{PM}_{2.5}$ concentrations increased significantly from $65 \mathrm{\mu g} \mathrm{m}^{-3}$ on non-haze days to $168 \mathrm{\mu g} \mathrm{m}^{-3}$ on no/blue-alert days and to $218 \mathrm{\mu g} \mathrm{m}^{-3}$ on redalert days.

When weather conditions stagnate under weak pressure gradients, the alert levels of heavy air pollution upgrade on haze days. The migratory anticyclones also shift the air masses, causing wide variations in chemical species and emission sources. During haze days, the $\mathrm{NO}_{2}$ and $\mathrm{NO}_{3}^{-}$concentrations exceed those of $\mathrm{SO}_{2}$ and $\mathrm{SO}_{4}^{2-}$, respectively, but the sulfur-containing species vary more widely than the nitrogen species. The sulfur compounds are particularly enhanced in stagnant air masses transported from the vicinity of Beijing, including the southern and eastern regions, leading to the large sulfur variation with little change in nitrogen. These results highlight the significant influence of emissions from industries requiring high energy and using coal and from local vehicles in the vicinity of Beijing on winter haze formation, which agrees with findings from previous studies (Hendrick et al., 2014; Wang et al., 2016). To abate the severe haze in Beijing, therefore, it is necessary to reduce vehicle emissions in Beijing and sulfur emissions from in- dustrial complexes and uncontrolled coal combustion in surrounding cities. For cost effectiveness, the weather forecast needs to be incorporated into the policy implementation.

\section{Conclusions}

This study investigated the chemical characteristics of $\mathrm{PM}_{2.5}$ during the 2013-2014 winter period in Beijing and identified its sources with an emphasis on haze events by measuring the particle masses, water-soluble ions, and trace elements in filtered samples. Finally, policy implications for controlling haze occurrences in Beijing were deduced from the analysis.

The samples were collected daily at CRAES, Beijing, China, from December of 2013 to February of 2014. During the winter period, the overall average $\mathrm{PM}_{2.5}$ concentration in Beijing was $89 \mu \mathrm{g} \mathrm{m}^{-3}$, exceeding the Chinese national standard of $75 \mu \mathrm{g} \mathrm{m}^{-3}$ in $24 \mathrm{~h}$. The excess was linked to high occurrence of haze events in February of 2014. The high $\mathrm{PM}_{2.5}$ episodes were concurrent with $\mathrm{PM}_{10}$ exceedance. Seventy percent of the samples were identified as developed type in the WHO criteria; that is, their $\mathrm{PM}_{2.5} / \mathrm{PM}_{10}$ ratios exceeded 0.5 . All 13 recognized haze events in this study were included in the developed type.

The chemical compositions showed that secondary ions were doubled on haze days relative to non-haze days, but mineral species were halved during haze events. For the 70 daily $\mathrm{PM}_{2.5}$ samples, NMF analysis was performed and the source profiles were compared between haze and nonhaze days. The analysis identified five principal sources, of which industrial emission, coal combustion, and traffic emission comprised similar fractions of 28,25 , and $22 \%$, respectively. The soil-dust and biomass-combustion sources were well distinguished and contributed 13 and $12 \%$, respectively. Comparing the source profiles between non-haze and haze 
events, the impact of soil dust was most noticeable on nonhaze days, when the air masses were transported rapidly from northwestern desert areas and brought high concentrations of $\mathrm{Ca}^{2+}$ and $\mathrm{Si}$ into Beijing. However, nearby transport of industrial, biomass combustion, and coal combustion emissions, along with local traffic emission, contributed to haze events under stagnant weather conditions. The contributions of these four sources increased by up to $61,35,37$, and $43 \%$ in no/blue-alert, orange-alert, and red-alert days, respectively. The industries that are mainly located to the west of Beijing use VOCs as raw materials, elevating the pseudocarbonaceous components in $\mathrm{PM}_{2.5}$. Biomass combustion increases during the firework displays of the Lantern Festival (14-16 February). At that time, the $\mathrm{K}^{+}$and $\mathrm{Mg}^{2+}$ concentrations are maximized. When a red alert was issued for 6 days in 2014, the contribution of $\mathrm{SO}_{4}^{2-}$ and $\mathrm{NO}_{3}^{-}$increased by factors of 3 and 2, respectively, from their non-haze levels. Overall, the sulfur compounds $\left(\mathrm{SO}_{2}\right.$ and $\left.\mathrm{SO}_{4}^{2-}\right)$ varied much more widely than the nitrogen compounds $\left(\mathrm{NO}_{2}\right.$ and $\mathrm{NO}_{3}^{-}$) through haze events, implying the substantial contribution of industrial emissions from coal combustion in surrounding cities. The high level of nitrogen compounds suggests local vehicle emissions as a main source of winter haze in Beijing. This study also emphasizes the role of weather conditions in haze formation by building up stagnant conditions that facilitate the transport of industrial emissions from the vicinity of Beijing. These findings will be applicable to policy making.

Data availability. Measurement data and analysis results are available upon request to the corresponding author (zhangkai@craes.org.cn or meehye@korea.ac.kr).

\section{The Supplement related to this article is available online at https://doi.org/10.5194/acp-18-2573-2018-supplement.}

Competing interests. The authors declare that they have no conflict of interest.

Acknowledgements. This study was performed as part of a ChinaKorea joint research project on air quality. Special thanks to the Chinese Research Academy of Environmental Sciences (CRAES) members including Pengli Duan, Fenmei Xia, Hongjiao Li, Zilong Zheng, Jing Zhou, Qingshu Ke, Jiaying Yang, and Jikang Wang, for help with sampling in Beijing. Kai Zhang would like to acknowledge support from the National Natural Science Foundation of China (no. 41205093), the National Department Public Benefit Research Foundation (no. 201109005), and the Fundamental Research Funds for Central Public Welfare Scientific Research Institutes of China (no. 2016YSKY-025). This work was supported by a grant from the National Institute of Environmental Research
(NIER), funded by the Ministry of Environment (MOE) of the Republic of Korea (NIER-2015-02-02-069). Meehye Lee also shows thanks for the support by Basic Science Research Program through the National Research Foundation of Korea (NRF) funded by the Ministry of Science, Information, and Communications Technology \& Future Planning (NRF-2017R1A2B4012143).

Edited by: Steven Brown

Reviewed by: two anonymous referees

\section{References}

Abuduwaili, J., Zhaoyong, Z., Jiang, F., and Liu, D.: The disastrous effects of salt dust deposition on cotton leaf photosynthesis and the cell physiological properties in the Ebinur basin in northwest China, PloS one, 10, e0124546, https://doi.org/10.1371/journal.pone.0124546, 2015.

Balasubramanian, R., Victor, T., and Begum, R.: Impact of biomass burning on rainwater acidity and com-position in Singapore, J. Geophys. Res., 104, 26881-26890, https://doi.org/10.1029/1999JD900247, 1999.

Baranyai, E., Simon, E., Braun, M., Tóthmérész, B., Posta, J., and Fábián, I.: The effect of a fireworks event on the amount and elemental concentration of deposited dust collected in the city of Debrecen, Hungary, Air Qual. Atmos. Health, 8, 359-365, https://doi.org/10.1007/s11869-014-0290-7, 2015.

CAAC 2013: Clean Air Alliance of China, State Council air pollution prevention and control action plan, issue II, October 2013, http://en.cleanairchina.org/product/6346.html (English translation), last access: 8 October 2015.

CAAC 2015: Clean Air Alliance of China, China Air Quality Management Assessment Report, Issue II, December 2015, http://en. cleanairchina.org/product/7386.html, last access: 30 May 2017.

Cai, W., Li, K., Liao, H., Wang, H., and Wu, L.: Weather conditions conducive to Beijing severe haze more frequent under climate change, Nat. Clim. Change, 7, 257-262, https://doi.org/10.1038/nclimate3249, 2017.

Cao, G. L., Zhang, X. Y., Gong, S. L., An, X. Q., and Wang, Y. Q.: Emission inventories of primary particles and pollutant gases for China, Chinese Sci. Bull., 56, 781-788, https://doi.org/10.1007/s11434-011-4373-7, 2011.

Chang, Y., Zou, Z., Deng, C., Huang, K., Collett, J. L., Lin, J., and Zhuang, G.: The importance of vehicle emissions as a source of atmospheric ammonia in the megacity of Shanghai, Atmos. Chem. Phys., 16, 3577-3594, https://doi.org/10.5194/acp16-3577-2016, 2016.

Chen, F., Zhang, X., Zhu, X., Zhang, H., Gao, J., and Hopke, P. K.: Chemical characteristics of $\mathrm{PM}_{2.5}$ during a 2016 winter haze episode in Shijiazhuang, China, Aerosol. Air. Qual. Res., 17, 368-380, https://doi.org/10.4209/aaqr.2016.06.0274, 2017.

Cheng, M., Zhi, G., Tang, W., Liu, S., Dang, H., Guo, Z., and Meng, F.: Air pollutant emission from the underestimated households' coal consumption source in China, Sci. Total Environ., 580, 641650, 2017.

Fu, Z., Zhai, Y., Wang, L., Zeng, G., Li, C., Peng, W., and Lu, P.: Morphological, geochemical composition and origins of nearsurface atmospheric dust in Changsha city of China, Environ. 
Earth Sci., 66, 2207-2216, https://doi.org/10.1007/s12665-0111442-9, 2012.

Guo, S., Hu, M., Zamora, M. L., Peng, J., Shang, D., Zheng, J., and Molina, M. J.: Elucidating severe urban haze formation in China, Proc. Natl. Acad. Sci., 111, 17373-17378, https://doi.org/10.1073/pnas.1419604111, 2014.

He, J., Wu, L., Mao, H., Liu, H., Jing, B., Yu, Y., Ren, P., Feng, C., and Liu, X.: Development of a vehicle emission inventory with high temporal-spatial resolution based on NRT traffic data and its impact on air pollution in Beijing - Part 2: Impact of vehicle emission on urban air quality, Atmos. Chem. Phys., 16, 31713184, https://doi.org/10.5194/acp-16-3171-2016, 2016.

Hendrick, F., Müller, J.-F., Clémer, K., Wang, P., De Mazière, M., Fayt, C., Gielen, C., Hermans, C., Ma, J. Z., Pinardi, G., Stavrakou, T., Vlemmix, T., and Van Roozendael, M.: Four years of ground-based MAX-DOAS observations of HONO and $\mathrm{NO}_{2}$ in the Beijing area, Atmos. Chem. Phys., 14, 765-781, https://doi.org/10.5194/acp-14-765-2014, 2014.

Hong, C., Zhang, Q., He, K., Guan, D., Li, M., Liu, F., and Zheng, B.: Variations of China's emission estimates response to uncertainties in energy statistics, Atmos. Chem. Phys. Discuss., https://doi.org/10.5194/acp-2016-459, in review, 2016.

Hu, G., Sun, J., Zhang, Y., Shen, X., and Yang, Y.: Chemical composition of $\mathrm{PM}_{2.5}$ based on two-year measurements at an urban site in Beijing, Aerosol Air Qual. Res., 15, 1748-1759, https://doi.org/10.4209/aaqr.2014.11.0284, 2015.

Huang, R. J., Zhang, Y., Bozzetti, C., Ho, K. F., Cao, J. J., Han, Y., and Zotter, P.: High secondary aerosol contribution to particulate pollution during haze events in China, Nature, 514, 218-222, https://doi.org/10.1038/nature13774, 2014.

Ji, D., Zhang, J., He, J., Wang, X., Pang, B., Liu, Z., and Wang, Y.: Characteristics of atmospheric organic and elemental carbon aerosols in urban Beijing, China, Atmos. Environ., 125, 293306, https://doi.org/10.1016/j.atmosenv.2015.11.020, 2016.

Jiang, J., Zhou, W., Cheng, Z., Wang, S., He, K., and Hao, J.: Particulate matter distributions in China during a winter period with frequent pollution episodes (January 2013), Aerosol Air Qual. Res., 15, 494-503, https://doi.org/10.4209/aaqr.2014.04.0070, 2015

Kfoury, A., Ledoux, F., Roche, C., Delmaire, G., Roussel, G., and Courcot, D.: $\mathrm{PM}_{2.5}$ source apportionment in a French urban coastal site under steelworks emission influences using constrained non-negative matrix factorization receptor model, J. Environ. Sci., 40, 114-128, https://doi.org/10.1016/j.jes.2015.10.025, 2016.

Lang, J., Zhang, Y., Cheng, S., Zhou, Y., Chen, D., Guo, X., Li, X., Xing, X., Chen, S., and Wang, H.: Trends of $\mathrm{PM}_{2.5}$ and chemical composition in Beijing, 2000-2015, Aerosol. Air. Qual. Res., 17, 412-425, https://doi.org/10.4209/aaqr.2017.01.0042, 2017.

Lee, D. D. and Seung, H. S.: Learning the parts of objects by non-negative matrix factorization, Nature, 401, 788-791, https://doi.org/10.1038/44565, 1999.

Lee, D. D. and Seung, H. S.: Algorithms for non-negative matrix factorization, Adv. Neural. Inf. Process Syst., 13, 556-562, 2001.

Liu, T., Gong, S., He, J., Yu, M., Wang, Q., Li, H., Liu, W., Zhang, J., Li, L., Wang, X., Li, S., Lu, Y., Du, H., Wang, Y., Zhou, C., Liu, H., and Zhao, Q.: Attributions of meteorological and emission factors to the 2015 winter severe haze pollution episodes in
China's Jing-Jin-Ji area, Atmos. Chem. Phys., 17, 2971-2980, https://doi.org/10.5194/acp-17-2971-2017, 2017.

Lim, S.: Source Signature of Ions and Carbonaceous Compounds in Submicron and Supermicron Aerosols at Gosan-super site, Jeju, South Korea, Master's thesis, Korea University, 2009.

Lu, Z., Streets, D. G., Zhang, Q., Wang, S., Carmichael, G. R., Cheng, Y. F., Wei, C., Chin, M., Diehl, T., and Tan, Q.: Sulfur dioxide emissions in China and sulfur trends in East Asia since 2000, Atmos. Chem. Phys., 10, 6311-6331, https://doi.org/10.5194/acp-10-6311-2010, 2010.

Ministry of Environmental Protection of the People's Republic of China, Ambient air quality standards (GB3095-2012), Chinese Environmental Science Press: Beijing, China, 2012 (in Chinese).

Peng, H., Liu, D., Zhou, B., Su, Y., Wu, J., Shen, H., Wei, J., and Cao, L.: Boundary-layer characteristics of persistent regional haze events and heavy haze days in eastern China, Adv. Meteorol., 6950154, https://doi.org/10.1155/2016/6950154, 2016.

Reff, A., Eberly, S., and Bhave, P.: Receptor modeling of ambient particulate matter data using positive matrix factorization: review of existing methods, J. Air Waste. Manage. Assoc., 57, 146-154, https://doi.org/10.1080/10473289.2007.10465319, 2007.

Stein, A. F., Draxler, R. R., Rolph, G. D., Stunder, B. J. B., Cohen, M. D., and Ngan, F.: NOAA's HYSPLIT atmospheric transport and dispersion modeling system, Bull. Amer. Meteor. Soc., 96, 2059-2077, https://doi.org/10.1175/BAMS-D-14$00110.1,2015$.

Tan, J., Duan, J., Zhen, N., He, K., and Hao, J.: Chemical characteristics and source of size-fractionated atmospheric particle in haze episode in Beijing, Atmos. Res., 167, 24-33, https://doi.org/10.1016/j.atmosres.2015.06.015, 2016.

van der A, R. J., Mijling, B., Ding, J., Koukouli, M. E., Liu, F., Li, Q., Mao, H., and Theys, N.: Cleaning up the air: effectiveness of air quality policy for $\mathrm{SO}_{2}$ and $\mathrm{NO}_{x}$ emissions in China, Atmos. Chem. Phys., 17, 1775-1789, https://doi.org/10.5194/acp17-1775-2017, 2017.

Wan, D., Han, Z., Yang, J., Yang, G., and Liu, X.: Heavy metal pollution in settled dust associated with different urban functional areas in a heavily air-polluted city in North China, Int. J. Environ. Res. Public Health, 13, E1119, https://doi.org/10.3390/ijerph13111119, 2016.

Wang, H.-J. and Chen, H.-P.: Understanding the recent trend of haze pollution in eastern China: roles of climate change, Atmos. Chem. Phys., 16, 4205-4211, https://doi.org/10.5194/acp16-4205-2016, 2016.

Wang, G., Zhang, R., Gomez, M. E., Yang, L., Zamora, M. L., $\mathrm{Hu}$, M., and Li, J.: Persistent sulfate formation from London Fog to Chinese haze, Proc. Natl. Acad. Sci., 113, 13630-13635, https://doi.org/10.1073/pnas.1616540113, 2016.

Wang, L. T., Wei, Z., Yang, J., Zhang, Y., Zhang, F. F., Su, J., Meng, C. C., and Zhang, Q.: The 2013 severe haze over southern Hebei, China: model evaluation, source apportionment, and policy implications, Atmos. Chem. Phys., 14, 3151-3173, https://doi.org/10.5194/acp-14-3151-2014, 2014.

Wang, M., Zhu, T., Zheng, J., Zhang, R. Y., Zhang, S. Q., Xie, X. X., Han, Y. Q., and Li, Y.: Use of a mobile laboratory to evaluate changes in on-road air pollutants during the Beijing 2008 Summer Olympics, Atmos. Chem. Phys., 9, 8247-8263, https://doi.org/10.5194/acp-9-8247-2009, 2009. 
Wang, M., Zhu, T., Zhang, J. P., Zhang, Q. H., Lin, W. W., Li, Y., and Wang, Z. F.: Using a mobile laboratory to characterize the distribution and transport of sulfur dioxide in and around Beijing, Atmos. Chem. Phys., 11, 11631-11645, https://doi.org/10.5194/acp-11-11631-2011, 2011.

Wang, Y., Yao, L., Wang, L., Liu, Z., Ji, D., Tang, G., Zhang, J., Sun, Y., Hu, B., and Xin, J.: Mechanism for the formation of the January 2013 heavy haze pollution episode over central and eastern China, Sci. China Earth Sci., 57, 14-25, 2014.

Wang, Y. Q., Zhang, X. Y., Sun, J. Y., Zhang, X. C., Che, H. $\mathrm{Z}$., and $\mathrm{Li}, \mathrm{Y}$.: Spatial and temporal variations of the concentrations of $\mathrm{PM}_{10}, \mathrm{PM}_{2.5}$ and $\mathrm{PM}_{1}$ in China, Atmos. Chem. Phys., 15, 13585-13598, https://doi.org/10.5194/acp-15-135852015, 2015.

World Health Organization: Air quality guidelines: global update 2005: particulate matter, ozone, nitrogen dioxide, and sulfur dioxide, World Health Organization, 2006.

Wu, J., Zhang, P., Yi, H., and Qin, Z.: What causes haze pollution? An empirical study of $\mathrm{PM}_{2.5}$ concentrations in Chinese cities, Sustainability, 8, 132, https://doi.org/10.3390/su8020132, 2016.

Wu, S., Lu, A., and Li, L.: Spatial and temporal characteristics of minimum temperature in winter in China during 1961-2010 from NCEP/NCAR reanalysis, Theor. Appl. Climatol., 108, 207-216, https://doi.org/10.1007/s00704-011-0525-6, 2012.

Wu, X., Huang, W., Zhang, Y., Zheng, C., Jiang, X., Gao, X., and Cen, K.: Characteristics and uncertainty of industrial VOCs emissions in China, Aerosol Air Qual. Res., 15, 1045-1058, https://doi.org/10.4209/aaqr.2014.10.0236, 2015.

Xie, Y. L., Hopke, P. K., Paatero, P., Barrie, L. A., and Li, S. M.: Identification of Source Nature and Seasonal Variations of Arctic Aerosol by positive matrix factorization, J. Atmos. Sci., 56, 249260, 1999a.

Xie, Y. L., Hopke, P. K., Paatero, P., Barrie, L. A., and Li, S. M.: Identification of source nature and seasonal variations of Arctic aerosol by the multilinear engine, Atmos. Environ., 33, 25492562, https://doi.org/10.1016/S1352-2310(98)00196-4, 1999 b.
Yang, K., Dickerson, R. R., Carn, S. A., Ge, C., and Wang, J.: First observations of $\mathrm{SO}_{2}$ from the satellite Suomi NPP OMPS: Widespread air pollution events over China, Geophys. Res. Lett., 40, 4957-4962, 2013.

Zhang, J. J. and Samet, J. M.: Chinese haze versus Western smog: lessons learned, J. Thorac. Dis., 7, https://doi.org/10.3978/j.issn.2072-1439.2014.12.06, 2015.

Zhang, K., Chai, F., Zheng, Z., Yang, Q., Li, J., Wang, J., and Zhang, Y.: Characteristics of atmospheric particles and heavy metals in winter in Chang-Zhu-Tan city clusters, China, J. Environ. Sci., 26, 147-153, 2014.

Zhang, Y. L. and Cao, F.: Fine particulate matter $\left(\mathrm{PM}_{2.5}\right)$ in China at a city level, Sci. Reports, 5, 14884, https://doi.org/10.1038/srep14884, 2015.

Zhang, R., Jing, J., Tao, J., Hsu, S.-C., Wang, G., Cao, J., Lee, C. S. L., Zhu, L., Chen, Z., Zhao, Y., and Shen, Z.: Chemical characterization and source apportionment of $\mathrm{PM}_{2.5}$ in Beijing: seasonal perspective, Atmos. Chem. Phys., 13, 7053-7074, https://doi.org/10.5194/acp-13-7053-2013, 2013.

Zheng, G. J., Duan, F. K., Su, H., Ma, Y. L., Cheng, Y., Zheng, B., Zhang, Q., Huang, T., Kimoto, T., Chang, D., Pöschl, U., Cheng, Y. F., and He, K. B.: Exploring the severe winter haze in Beijing: the impact of synoptic weather, regional transport and heterogeneous reactions, Atmos. Chem. Phys., 15, 2969-2983, https://doi.org/10.5194/acp-15-2969-2015, 2015.

Zheng, G., Duan, F., Ma, Y., Zhang, Q., Huang, T., Kimoto, T., and He, K.: Episode-based evolution pattern analysis of haze pollution: method development and results from Beijing, China, Environ. Sci. Technol., 50, 4632-4641, https://doi.org/10.1021/acs.est.5b05593, 2016. 